\title{
Metabotropic Glutamate Receptors in Peripheral Tissues: Implications for Toxicology
}

\author{
Daniela Durand, Lila Carniglia, Carla Caruso and Mercedes Lasaga \\ Research Institute for Reproduction, School of Medicine, \\ University of Buenos Aires, \\ Argentina
}

\section{Introduction}

Glutamate, the main excitatory neurotransmitter in the central nervous system (CNS), signals through ionotropic receptors (iGluRs), including AMPA, kainate and NMDA receptors, which are glutamate-gated ion channels and regulate rapid responses upon activation, and metabotropic receptors (mGluRs), which evoke slower responses through activation of intracellular transduction cascades. mGluRs are single peptide seven-transmembrane spanning proteins linked to intracellular G-proteins although it has been reported that Gprotein-independent signalling can occur (Heuss et al., 1999). Eight different mGluRs (mGluR1-8) have been cloned and classified into three groups (groups I, II and III) based on sequence homology and the intracellular signal transduction pathways they activate. Group I metabotropic glutamate receptors include mGluR1 and mGluR5 subtypes, which activate phospholipase $\mathrm{C}$ and induce inositol triphosphate production and intracellular calcium mobilization. Group II mGluRs include mGluR2 and mGluR3 subtypes, whereas Group III mGluRs include mGluR4, mGluR6, mGluR7 and mGluR8 subtypes. All these receptors are negatively coupled to adenylyl cyclase signalling, resulting in inhibition of cyclic AMP production. Since mGluRs are expressed by neurons and glia near the synaptic cleft, where they modulate not only the effect of glutamate on the postsynaptic neurons but also the release of glutamate and other neurotransmitters, it is though that the mGluR system has evolved as a modulating mechanism for controlling excitability into the CNS (Schoepp, 2001). Furthermore, several mGluR subtypes were shown to exert glial and neuro-protective actions in distinct pathological conditions (Bruno et al., 1998; Kingston et al., 1999; D'Onofrio et al., 2001; Ciccarelli et al., 2007; Durand et al., 2010). However, mGluRs have currently received much attention motivated by a strong belief in their potential as drug targets for treatment of anxiety disorders and schizophrenia (Lavreysen \& Dautzenberg, 2008; Chaki et al., 2010; Mezler et al., 2010; Schlumberger et al., 2009; Moreno et al., 2009; Patil et al., 2007).

The strongest suggestion that mGluRs are not exclusively synaptic receptors derives from numerous studies that demonstrate the presence of functional mGluRs in a number of peripheral non-neuronal cells, many of which do not even originate from the neural crest (Nicoletti et al., 2007), shifting the role of these receptors from mere synaptic regulators to modulators of basic cell functions (such as cell proliferation, differentiation and survival) 
and key mediators of peripheral tissue function and neuroendocrine events. Besides organs that receive direct glutamatergic innervations, such as the heart and the adrenal glands, peripheral mGluRs can be activated in the absence of synaptic glutamate because of the existence of a large metabolic glutamate pool into cells derived from the Krebs cycle (Nicoletti et al., 2007). Then, metabolic glutamate can be transported outside the cell where it activates paracrine or autocrine mechanisms on cells expressing glutamate receptors.

As implied by the evidence above, the use of selective mGluR agonists and antagonists as therapeutic agents in treatment of anxiety disorders rises the problem of undesirable side effects in these patients. Therefore, in an effort to warn against unsafeness of clinical trials in the area of the anxiety disorders, this chapter summarizes current knowledge of the distribution and actions of mGluRs outside the brain.

\section{2. mGluRs and anxiety}

Several mGluR ligands were proved to have high efficacy for treatment of anxiety disorders: the mGluR1 antagonist JNJ16259685 and the mGluR5 antagonist MPEP showed anxiolytic effects in rodents (Spooren et al., 2000; Steckler et al., 2005a); group II mGluR agonists LY354740, LY379268 and LY404039 showed therapeutic actions in both anxiety and schizophrenia (Schoepp, 2004), whereas LY2140023 is entering phase II/III trials for schizophrenia (Eli Lilly, 2010).

While benzodiazepines exert their anxiolytic effect by binding to the $\gamma$-aminobutyric acid (GABA) receptors enhancing the inhibitory action of GABA in the CNS (Stahl, 2000); buspirone acts as a serotonin (5-HT) $)_{1 \mathrm{~A}}$ receptor agonist (Ninan et al., 1998); propranolol is a $\beta$-blocker which arrests the autonomic arousal experienced during stress and anxiety (Noyes, 1985); and hydroxyzine is an antihistamine (Choy, 2007), the mechanism of anxiolytic action of mGluR ligands has not been completely elucidated. Currently, it is believed that their anxiolytic effects correlate with suppression of enhanced glutamatergic excitation at brain synapses involved in fear/anxiety in animals and humans (Schoepp et al., 2003), an action which is related to the synapse modulating function of these receptors. In addition, mGluR2/3 agonists regulate dopamine release and 5-HT2A receptor activity, which have been presumed to be involved in their antipsychotic action (Chaki et al., 2010). It is now known that typical antipsychotic administration derives in multiple side effects such as extrapyramidal symptoms, tardive dyskinesia, hypertension or weight gain. Benzodiazepines, for example, although effective and well tolerated, present associated risks including drug-drug interactions, pregnancy problems, psychomotor impairment, memory problems, and physiologic dependence (Choy, 2007). More recently developed atypical antipsychotics like risperidone or clozapine also were associated with weight gain, diabetes, hyperlipidemia, arrhythmia, hyperprolactinemia-related sexual dysfunctions, dystonic reactions, caratact, and insomnia (Üçok \& Gaebel, 2008). Therefore, it is noteworthy that mGluR ligands with antipsychotic properties were not shown to induce the commonest adverse effects at date. However, mGluR agonists/antagonists may present a different set of adverse effects, considering their vast range of target peripheral organs.

\section{3. mGluRs in endocrine organs}

The initial demonstration of a role for glutamate on neuroendocrine regulation resulted from the observation that neonatal administration of monosodium glutamate was followed 
by brain lesions and obesity (Olney, 1969). Later, glutamate was shown to act on endocrine function mostly by modulating hypothalamic activity which in turn alters hormone release, but can also activate its receptors on pinealocytes, pancreatic cells, adrenal and sexual glands, further regulating hormone production and endocrine homeostasis.

Both glutamate and its receptors are localized in a variety of hypothalamic nuclei considered critical for reproduction and neuroendocrine function. mGluRs have been found not only in different regions within the hypothalamus such as the paraventricular nucleus (PVN), the ventromedial $(\mathrm{VMN})$, arcuate (ARC), supraoptic (SON) nuclei and the preoptic area (POA), but also in the three lobes of the pituitary gland (Meeker et al., 1994), exerting regulatory actions on the hypothalamic-pituitary axis.

\subsection{Effects of mGluRs on prolactin release}

Glutamate regulates basal prolactin secretion and also affects the physiological response of this hormone to stimuli such as suckling and stress (Nagy et al., 2005). Johnson \& Chamberlain (2002) suggested that LY379268, a group II mGluR agonist, produces disinhibition of tubero-infundibular dopamine release, which in turn increases prolactin secretion.

On the other hand, we demonstrated that group II mGluRs are present in lactotropes in rat anterior pituitary, which tallies with functional data showing that L-CCG-I, a group II mGluR agonist, decreases prolactin release from anterior pituitary gland (Caruso et al., 2004). We also showed that L-CCG-I induces apoptosis in lactotropes (Caruso et al., 2004), which may account for the inhibition in prolactin secretion exerted by these receptors.

Interestingly, we also observed that group II mGluR agonists LY379268 and LY354740 may have a partial dopamine agonist action since they bind to D2 receptors in rat striatum and to human cloned D2Long receptors in CHO cells (Seeman et al., 2008). This action could lead to an inhibition of prolactin release from anterior pituitary cells. Concordantly, LY379268 can reduce hyperprolactinemia under several conditions in rats (Johnson \& Chamberlain, 2002). It is likely that the actions of these agonists in vivo involve both glutamate and dopamine components (Cartmell et al., 2000).

All these facts agree with the lack of hyperprolactinemia, one of the most frequent side effects of antipsychotic drugs, after mGluR ligand administration (Patil et al., 2007).

\subsection{Effects of mGluR activation on hypothalamic neuropeptide release which regulates LH secretion}

Evidence from our laboratory indicates that glutamate-induced release of substance P (SP) in the rat ARC and median eminence is mediated via activation of NMDA and group I mGlu receptors (Caruso et al., 2006). Since SP has been shown to stimulate prolactin and luteinizing hormone (LH) secretion, induction of SP release may mediate, at least in part, the stimulatory effect of glutamate on LH and prolactin secretion (Debeljuk \& Lasaga, 1999).

Glutamate can regulate hypothalamic oxytocin release through activation of AMPA and mGlu receptors (Pampillo et al., 2001). Schrader \& Tasker (1997a) found that activation of group I mGluRs reduced $\mathrm{K}^{+}$currents in SON magnocellular neurons, suggesting the presence of group I mGluRs in this hypothalamic area. In fact, we reported that group I mGluRs participate in the stimulatory effect of glutamate on hypothalamic oxytocin release in adult male rats (Pampillo et al., 2001). Morsette et al. (2001) also showed that group I mGluR activation increased oxytocin release in rat hypothalamo-neurohypophysial 
explants. The increase in hypothalamic oxytocin release following group I mGluR activation would determine a rise in gonadotropin-releasing hormone $(\mathrm{GnRH})$ release (van den Pol et al., 1990), and consequently a stimulation of LH release from the anterior pituitary. Interaction between oxytocin receptor and mGluR1 was proposed. In hypothalamic rat astrocytes, antagonism of mGluRla leads to a decrease in oxytocin-induced $\left[\mathrm{Ca}^{2+}\right]_{\mathrm{i}}$ response whereas the agonist DHPG potentiates the oxytocin response (Kuo et al., 2009).

Morsette et al. (2001) demonstrated a concentration-dependent stimulation of vasopressin (VP) release when hypothalamo-neurohypophysial explants were perifused with group I mGluR agonists.

Activation of both group I and II mGluRs decreases alpha melanocyte stimulating hormone $(\alpha-\mathrm{MSH})$ release from hypothalamic fragments (Pampillo et al., 2002a). Since $\alpha-\mathrm{MSH}$ inhibits preovulatory prolactin and LH surge and ovulation of female rats (Crown et al., 2007), mGluRs activity at $\alpha$-MSH level could lead to increased LH production.

It is widely accepted that glutamate plays important roles in controlling GnRH neuron excitability, probably acting at the preoptic region of the hypothalamus (Gu et al., 1999). Only small sub-populations of GnRH neurons have functional mGluRs (Iremonger et al., 2010). A subpopulation of GnRH neurons in the medial septum was found to be excited by group I mGluR agonists (Dumalska et al., 2008). Nevertheless, we also know that activation of presynaptic group II/III mGluRs inhibits GABAergic input to GnRH neurons. Since GABA is involved in generation and modulation of the rhythm of GnRH release, mGluR could be affecting GnRH release (Chu \& Moenter, 2005). Therefore, activation of mGluRs could inhibit GnRH release, at least in part thereby acting on GABAergic transmission. On the contrary, Lopez et al. (1992) and Pampillo et al. (2002b) reported that group I and II mGluR activation did not affect hypothalamic $\mathrm{GnRH}$ release in vitro.

In summary, actions of group I mGluRs on SP, oxytocin, VP and $\alpha-\mathrm{MSH}$ at hypothalamic level seem to indicate that the use of group I mGluR antagonists as anxiolytic drugs could ultimately lead to decreased prolactin and LH surge.

\subsection{Effect of mGluRs on Growth Hormone (GH) release}

Aguilar et al. (2005) showed changes in GH secretion following administration of mGluR agonists to prepubertal animals: a significant decrease in serum $\mathrm{GH}$ concentrations after central (i.c.v.) administration of t-ACPD (a group I and II mGluR agonist) and following systemic administration of ibotenic acid (a weak agonist of all mGluRs). We have shown the presence of group II mGluRs in somatotropes and we observed an apoptotic effect of LCCGI, a group II mGluR agonist, on this cell type (Caruso et al., 2004). mGluR inhibitory effects contrast with the potent stimulatory actions observed following iGluR activation (Aguilar et al., 2005). Thus, it becomes apparent that L-glutamate is able to exert a dual regulatory action upon GH secretion, which involves a predominant stimulatory effect via iGluRs, as well as a minor inhibitory effect via mGluRs.

\subsection{Actions of mGluR activation on hypothalamic-pituitary-adrenal (HPA) axis}

HPA axis is the key regulator of stress reaction. t-ACPD induced a significant increase in plasma corticosterone following i.c.v. administration (Lang \& Ajmal, 1995). Jonhson et al. (2001) reported that treatment with either an agonist or antagonist of group I mGluRs results in a rise in serum corticosterone. The authors suggest that this paradoxical action may be due to a direct stimulatory effect of group I mGluR agonists on CRH release whereas selective 
mGluR1 and mGluR5 antagonists may increase CRH release through disinhibiton of GABAergic interneurons. Concordantly, a selective mGluR5 antagonist increases circulating ACTH and corticosterone concentrations (Bradbury et al., 2003). On the other hand, an antagonist of group II mGluRs increased plasma corticosterone and $\mathrm{CRH}$ secretion from isolated hypothalami while group II mGluR agonists induced no modifications (Scaccianoce et al., 2003). The lack of effect of group II mGluR agonists supports the hypothesis that endogenous activation of group II mGluR could tonically inhibit hypothalamic CRH release.

It has also been demonstrated that i.c.v. administration of nonselective group III mGluR agonists L-AP4 and L-SOP induced an increase in corticosterone levels (Johnson et al., 2001). Mitsukawa et al. (2006) showed that mGluR7 subtype plays a role in the increase of stress hormones induced by group III mGluR agonists. AMN082, an allosteric agonist of mGluR7, induced a robust increase in stress hormone levels that was absent in mGluR7 knockout animals (Conn \& Niswender, 2006). Group III mGluRs regulate the activity of GABA interneurones in the hypothalamus (Schrader \& Tasker, 1997b) by decreasing L-glutamate release. Consequently, there would be decreased tone in GABAergic interneurons and a disinhibition of CRH neurons.

In summary, although the HPA axis is activated by mGluR1/5 antagonists and group III mGluR agonists, this effect does not seem to interfere with the anxiolytic role of these ligands.

\subsection{Pancreas}

Although the presence and function of iGluRs in pancreatic tissue is quite well defined, there is still no consensus regarding expression of mGluRs in pancreatic islets. Brice et al. (2002) found mGluR3 and mGluR5 mRNA and protein in rat and human islets of Langerhans; mGluR8 expression was detected in rat islets; and mGluR4 was detected in rat islets but not in $\alpha$ or $\beta$ cell lines (therefore, they could be expressed in $\delta$ cells). In consonance with these findings, mGluR3, mGluR5 and mGluR8 activation improved release of insulin from a $\beta$ cell line in the presence of glucose, although mGluR8 activation inhibited insulin release at higher glucose concentrations (Brice et al., 2002).

On the opposite side, Uehara et al. (2004) reported evidence for functional occurrence of mGluR4, but not other mGluRs, in alpha and F pancreatic cells, its activation showing an inhibitory effect on glucagon secretion by reducing cAMP production. Thus, mGluR4mediated signaling pathway might provide a molecular basis for chemotherapeutics for hyperglycemia, one of the symptoms of type 2 diabetes. However, Tong et al. (2002) demonstrated mGluR8 (not mGluR4)-dependent inhibition of glucagon release from rat pancreatic islets. Taking a third position, Cabrera et al. (2008) found no effect of mGluR agonists on glucagon secretion using human islets.

In an animal model of diabetes, upregulation of mGluR5 causes cell damage and neurodegeneration (Anu et al., 2010). However, other authors reported that endogenous activation of mGluR5 is required for optimal insulin response to glucose in mice and is also involved in the correct glucagon response to insulin challenge (Storto et al., 2006). Intracerebroventricular injection of ACPD (a group I and II mGluR agonist) increases plasma glucose, insulin and glucagon levels (Lang \& Ajmal, 1995). Adult mice lacking mGluR5 weighed significantly less than littermate controls and, on a high fat diet, mGluR5 -/- mice weighed less and had decreased plasma insulin and leptin concentrations (Bradbury et al., 2005). 


\subsection{Pineal gland}

Pinealocytes express mGluR3 and mGluR5. Indeed, group II mGluR agonists inhibit norepinephrine-stimulated melatonin synthesis and N-acetyltransferase activity, possibly involving the mGluR3 subtype expressed in rat pineal gland (Yamada et al., 1998). Glutamatergic communication system of the pineal gland may not only enable paracrine crosstalk among pinealocytes but also probably relies on interactions between pinealocytes and interstitial cells analogous to neuronal-glial signaling (Pabst \& Redecker, 1999). The evidence indicates that sleep disrupts can be associated with mGluR function.

\section{Other organs}

\subsection{Kidney}

In the rat kidney the presence of mGluR2/3 has been described in the juxtaglomerular apparatus and proximal tubules, suggesting that these receptors may be involved in electrolytes and water homeostasis (Gill \& Pulido, 2001). In addition, strong immunoreactivity for mGluR2/3 was observed in granular cells of the afferent arteriole (Gill \& Pulido, 2001), indicating a possible role in the control of renin release, a hormone which belongs to the renin-angiotensin system involved in regulation of electrolyte, fluid balance and blood pressure (Jackson et al., 1985). In human kidney, focal expression of mGluR4 was detected in the collecting duct (Chang et al., 2005), whereas positivity of a normal mouse glomerulus for mGluR7 was found along the glomerular basement membrane (Rastaldi et al., 2006).

\subsection{Liver and gastrointestinal tract}

One of the first studies reporting the presence of mGluRs in peripheral organs showed the ability of group I mGluR agonists to stimulate phosphoinositide hydrolysis in primary cultures of rat hepatocytes (Sureda et al., 1997). In subsequent studies, expression of mGluR5, but not mGluR1, and mGluR3 in rat liver was demonstrated (Do et al., 2007; Storto et al., 2000a). Moreover, mGluR3 were shown to be up-regulated in response to persistent hypoxic status such as fibrotic/cirrhotic conditions in rat liver macrophages, exerting a role in functional metabolism and viability in this tissue (Do et al., 2007), although it has been shown that an agonist of mGluR2/3 had no effect on rat hepatocyte death induced by anoxia (Storto et al., 2000a). On the contrary, endogenous mGluR5 activation is associated with liver damage induced by lipopolysaccharide and d-galactosamine (Jesse et al., 2009) or by acetaminophen in mice (Storto et al., 2003). In turn, selective blockade of mGluR5 protects against hepatocyte death induced by hypoxia (Storto et al., 2004) and oxidative stress (Storto et al., 2003) in rodents.

mGluR5 antagonists have proved to be useful in the treatment of gastroesophageal gastric reflux in clinical trials (Bolea et al., 2004; Zerbib et al., 2010). mGluR8 agonists also have protective effects on esophageal sphincter relaxation (Frisby et al., 2005). mGluR1-8 mRNA expression has been detected in different cell components of rat stomach mucosa (Nakamura et al., 2010), whereas intense mGluR2/3 protein staining was found in both parietal and endocrine cells, suggesting a role in the regulation of gastric acid and gastrin secretion (Gill \& Pulido, 2001). mGluR1 is also located in glandular stomach and glutamate induces changes in the expression of pepsinogen (San Gabriel et al., 2007). mGluR1/5 signaling may increase intracellular $\mathrm{pH}$ in the duodenum (Akiba et al., 2009). The presence of mGluR2/3 and mGluR1/ 5 has been demonstrated in neurons of jejunum and ileum, suggesting that they may 
play a role in the regulation of intestinal motility (Larzabal et al., 1999; Liu \& Kirchgessner, 2000; Nasser et al., 2007). On the other hand, mGluR4 and mGluR7 are expressed in colon mucosa (Chang et al., 2005; Julio-Peper et al., 2010). Activation of mGluR7 in the colon could be a component of secretory disorders such as stress-induced diarrhea (Julio-Peper et al., 2010). mGluR8 is also present in the enteric nervous system and their activation by selective agonists increases colon motility (Tong \& Kirchgessner, 2003).

Thus, apparently, no major adverse effects are expected to be induced by group I mGluR antagonists or group II mGluR agonists in the normal or anoxic/cirrhotic liver or in the gastrointestinal tract.

\subsection{Reproductive system}

Most currently available studies involving mGluRs in both female and male reproductive systems include only descriptive, anatomical analyses, although the unique distribution of mGluRs in sex organs suggests their participation in reproductive events such as germinal cell development, testicular development, sex hormone production and cyclic cell turnover.

In humans, immunoreactivity for mGluR1 was restricted to Leydig cells of intertubular spaces, where their activation could likely stimulate testosterone synthesis. mGluR5 was highly expressed in human seminiferous tubuli and in the mid-piece and tail of mature spermatozoa, even though neither mGluR5 agonist nor antagonist changed human sperm motility (Storto et al., 2001).

A strong immunolabeling for mGluR2/3 is present in the oocyte, the theca, and granulose cells in the macaque ovary (Gill et al., 2008). Likewise, in rat ovary, the oocyte showed intense staining for mGluR2/3, whereas the corpus luteum was moderately immunoreactive (Gill \& Pulido, 2001). mGluR4 has been found in the human cervix and is weakly expressed in the endometrial glands (Chang et al., 2005). mGluR2/3 show positive immunoreactivity for the most superficial layer of the stratified squamous epithelium of the exocervix in rat uterus (Gill \& Pulido, 2001). mGluR2/3 expression is predominant in proliferating ovarian and uterine structures, which indicates that its production may be cyclically regulated (Julio-Pieper et al., 2011).

All this evidence indicates that these receptors may be involved in ovulation, fertilization, implantation of the ovum and excitability of the uterus (Gill \& Pulido, 2001). However, the only studies actually establishing a relationship between mGluRs and reproductive events are those which demonstrated a physiological interaction between estrogen receptors and mGluRs in both neurons and astrocytes (Dewing et al., 2007; Kuo et al., 2009). In the brain, estrogen receptor $\alpha$ interacts with mGluR1 to increase $\left[\mathrm{Ca}^{2+}\right]_{i}$ flux and to initiate lordosis behavior and increases neuroprogesterone synthesis, which is a necessary step for estrogen positive feedback (Micevych et al., 2010). On the other hand, females treated neonatally with kainate, the type I/II metabotropic agonist ACPD, or both agonists combined showed adult male sexual behavior, indicating the participation of these glutamate receptor subtypes in masculinization (Wright \& McCarthy, 2009).

Therefore, this evidence supports actual mGluR-mediated reproductive events and implications for fertility rise regarding administration of mGluR ligands for psychiatric disorders. Likewise, mGluRs are involved in embryonic development, as mGluR3 induce differentiation of neural stem cells (Ciceroni et al., 2010) whereas a switch from high mGluR5 expression to mGluR4 expression is found in embryoid bodies resembling embryogenesis (Cappuccio et al., 2006). 


\subsection{Immune system and thymus}

mGluR activation has been proposed to play a similar role in the nervous and the immune systems by counteracting negative glutamate effects (Boldyrev et al., 2005). Since high levels of glutamate inhibit the proliferation of T-cells, glutamate has been related to immune deficiency (Ferrarese et al., 2001). Most attention has been focused on mGluR expression in thymocytes and T lymphocytes. Thymocytes express group I and II mGluRs (Storto et al., $2000 \mathrm{~b}$ ). Another study showed the presence of group III mGluRs in thymic cells (Rezzani et al., 2003). Group III mGluR activation may lead to oxidative stress and cell death of peripheral lymphocytes, a deleterious action potentiated by the presence of NMDA (Boldyrev et al., 2004, 2005). On the other hand, glutamate, acting via mGluR1 and mGluR5, has beneficial effects on human peripheral lymphocytes against activation-induced cell death (Miglio et al., 2005) or by inhibiting apoptosis induced by anti-CD3 treatment (Chiocchetti et al., 2006).

Pacheco et al. (2004) demonstrated that mGluR1 expression in human peripheral lymphocytes is detected after activation of the T-cell receptor CD3 complex, whereas mGluR5 is constitutively present (Pacheco et al., 2007), indicating that the expression of mGluRs in these immune cells depends on T-cell activation.

An antagonist of mGluR5 increased IL-6 secretion whereas an mGluR1 antagonist decreased the release of IL6, among other pro-inflammatory cytokines such as TNF-alpha and IFNgamma (Pacheco et al., 2006), suggesting different signaling pathways of these mGluR subtypes in lymphocytes. Moreover, glutamate via group I mGluRs, regulates the initiation of T-cell-mediated immune responses (Pacheco et al., 2006).

mGluRs also seem to play a role in the development of autoimmune-related disorders (JulioPieper et al., 2011). For example, activation of mGluR4 in dendritic cells might exert a protective effect by preventing unbalance in $\mathrm{T}$ helper cells in a model of multiple sclerosis (Fallarino et al., 2010).

\subsection{Heart}

In animal and human hearts mGluR expression and effects on cardiac function have been reported. In rat heart, mGluR1, mGluR2/3 and mGluR5 are localized preferentially in the atrial nerve terminals, ganglion cells, and elements of the conducting system (Gill et al., 1999). In mouse heart, Moore-Morris et al. (2009) identified the mGluR1b transcript, which is functional in ventricular cardiomyocytes. In macaque heart, mGluR2/3 and 5 were found in myocardial nerve fibers, atrial intramural ganglia and myocytes, ventricular and submyocardial myocytes, Purkinje fibers, and bundle of Hiss (Mueller et al., 2003). In the human heart, mGluR1 and 5 but not mGluR2/3 were found in atrial intramural ganglia, atrial and ventricular cardiocytes, and bundle of Hiss (Gill et al., 2007).

Regarding the participation of the mGluR system in heart function, it has been shown that anteroventral third ventricular region infusion of mGluR agonist $t$-ACPD produced dosedependent rises in plasma vasopressin, arterial pressure and heart rate after 5 or $15 \mathrm{~min}$, although t-ACPD administration into the cerebral ventricle had no effect on these variables (Yamaguchi \& Watanabe, 2004). Accordingly, group I, II and III mGluR agonists produced significant increases in arterial pressure and heart rate, although the respective antagonists failed to inhibit these cardiovascular responses (Tsuchihashi et al., 2000).

Nevertheless, opposite results were reported by others as follows. Microinjection of t-ACPD into the commissural subnucleus of the nucleus tractus solitarii elicited bradycardia (Braga et al., 2006). Activation of mGluR1, mGluR2/3, mGluR4 and mGluR8 into the nucleus tractus solitarius of anesthetized male Wistar rats elicited depressor and bradycardic 
responses (Viard \& Sapru, 2002). Furthermore, activation of spinal group I, II and III mGluRs increased the mean blood pressure in anesthetized rats while, after blockade of NMDA receptors, low doses of group II mGluR agonists induced hypotension and bradycardia (Celuch \& García, 2002), suggesting that the main effects of mGluR agonist administration on cardiovascular function may depend on the dose used. Other authors have postulated that, in general, group I and II mGluRs produce responses consistent with excitation of neurons involved in reducing sympathetic outflow, heart rate, and arterial pressure (Foley et al., 1999; Jones et al., 1999).

These contradictory results make our interpretation of mGluR effects on cardiac function difficult. However, no adverse cardiovascular reactions were reported after mGluR ligand administration in patients with anxiety disorders.

\subsection{Sense organs}

mGluR1 and mGluR4, present in mammalian taste buds, sense umami taste elicited by monosodium glutamate (Chaudhari et al., 2009). The function of taste mGluR1 may be relevant in the back of the tongue. mGluR2 and mGluR3 mRNAs were also found in the circumvallate papillae, in cells co-expressing gustducin (Toyono et al., 2007).

mRNAs for seven of the eight mGluRs are expressed in the olfactory system, their expression being particularly high in the accessory olfactory bulb (Castro et al., 2007). In fact, under control conditions, recurrent inhibition of principal neurons (mitral cells) in accessory olfactory bulb slices was completely eliminated by mGluR1 antagonists (Castro et al., 2007). It has been suggested that mGluR2 might be involved in behavior associated with pheromone chemosignals (Nolte \& Meredith, 2005).

All mGluRs except mGluR3 have been identified in the retina, with a differential distribution depending on the cell layers of retina (Connaughton, 2005), whereas mGluR6 activation have physiological significance (Gerber, 2003). In fact, defects in mGluR6 gene lead to congenital stationary blindness (Julio-Pieper et al., 2011). mGluR8 were clearly found in photoreceptor terminals in mammalian retina (Brandstätter et al., 1998; Koulen et al., 1999), their activation causing a decrease in $\left[\mathrm{Ca}^{2+}\right] \mathrm{i}$ in isolated rat photoreceptors (Koulen et al., 1999) and preventing glutamate excitotoxicity. mGluR1 and 5 may modulate responses of ON bipolar cells to neurotransmitters (Koulen et al., 1997). mGluR1/5, mGluR2 and mGluR4/7/8 have also been reported to be present in amacrine cells (Hartveit et al., 1995; Brandstätter et al., 1998) and rat ganglion cells (Akazawa et al., 1994; Hartveit et al., 1995).

Glutamate is thought to be the afferent neurotransmitter in the auditory system. In situ hybridization showed that mGluR1 alpha mRNA was expressed by type I and type II spiral ganglion neurons in the cochlea, although at low levels (Safieddine \& Eybalin, 1995), suggesting that mGluR1alpha play a minor role in auditory transmission. Group I mGluRs expressed by SCC hair cells may serve as a mechanism for selective amplification of mechanically evoked transmitter release, thereby enhancing signal discrimination (Hendricson \& Guth, 2002). Group I mGluRs contribute to neurotransmission between inner hair cells and afferent neurons in mammalian cochlea (Kleinlogel et al., 1999). Activation of group II mGluRs is able to increase the release of dopamine in guinea pig cochlea, via a disinhibitory mechanism involving local GABAergic fibers, reducing glutamate excitotoxicity (Doleviczényi et al., 2005). On the other hand, mGluR7 is expressed in hair cells and in spiral ganglion cells of the inner ear, being associated with age-related hearing impairment (Friedman et al., 2009). 
The widespread distribution and multiple actions of mGluR subtypes in sense organs suggest possible deleterious effects of mGluR ligands on sense function.

\subsection{Bone}

Glutamate was identified in nerve fibers running through bone marrow in close contact with bone cells, suggesting that it may also act as a neuromediator in this tissue and may contribute to the regulation of bone remodeling (Chenu, 2002). Gu \& Publicover (2000) reported expression of mGluR1 in rat femoral osteoblasts by RT-PCR, whereas only mGluR4 and 8 mRNAs were detected in rat cultured calvarial osteoblasts (Hinoi et al., 2001). The mRNA and protein for mGluR6 were identified in rat femoral marrow stromal cells from the osteoblast lineage, where their activation suppressed generation of nitric oxide, which is pivotal to bone physiology (Foreman et al., 2005). Occurrence of mGluR3, 5 and $8 \mathrm{mRNA}$ was identified in mouse osteoclast, although only mGluR8 were found in mature osteoclasts (Morimoto et al., 2006). A specific mGluR8 agonist decreased $\mathrm{KCl}$-evoked secretion of glutamate and bone degradation products (Morimoto et al., 2006). Therefore, glutamate, via mGluR8, is though to exert negative autocrine feedback, keeping osteoclasts in a suppressed state and preventing osteoporosis. In fact, vesicular glutamate transporter 1 (VGLUT1)-/mice develop osteoporosis (Morimoto et al., 2006).

Cultured rat costal chondrocytes express mGluR1, 2, 4 and 8 and a group III mGluR agonist inhibits parathyroid hormone secretion through cAMP inhibition (Wang et al., 2005). Furthermore, chondral mineralization is greatly inhibited by group II and III mGluR activation in cultured embryonic mouse metatarsals by a mechanism involving apoptosis mediated by the depletion of intracellular glutathion (Wang et al., 2006).

Thus, there could be major implications for bone remodeling and chondral mineralization impairment by mGluR system-associated anxiolytic drugs.

\section{5. mGluRs, tumor growth and cancer development}

Stepulak et al. (2009) compiled data demonstrating that glutamate receptors are expressed in a variety of cancer cell lines (of neuronal and non-neuronal origin) and tumors, i.e., glioma, colorectal and gastric cancer, oral squamous cell carcinoma, prostate cancer, melanoma and osteosarcoma. It is also believed that the metabolic properties of tumors combined with altered metabolism in patients with cancer contribute to abnormally elevated glutamate plasma concentrations in these patients (Dröge et al., 1988). In turn, this excess of glutamate may activate its receptors and trigger intracellular signaling pathways, which may affect growth, survival and proliferation of cancer cells (Stepulak et al., 2009).

mGluR2 and mGluR7 were found to be expressed in all U87-MG and U343 (glioma), SKNA-S (neuroblastoma), TE671 (rhabdomyosarcoma/medulloblastoma), MOGGCCM (astrocytoma), SK-LU-1 (lung carcinoma), HT29 and LS180 (colon adenocarcinoma), Jurkat E6.1 (T cell leukemia cells), RPMI 8226 (multiple myeloma), T47D (breast carcinoma), and FTC (thyroid carcinoma) cancer cell lines (Stepulak et al., 2009). Expression of the other 6 subtypes of mGluR varied between these cell lines, although they were present in most of them. Also, mGluR3 mRNA is increased by 5 -fold in aldosterone-producing adenomas compared to normal human adrenal glands (Ye et al., 2007).

Ectopic expression of mGluR1 in human normal melanocytes, which normally lack this receptor, resulted in melanocyte hyperproliferation and transformation into malignant 
tumors that set off distant metastases (Nicoletti et al., 2007; Marin \& Chen, 2004). In the clinical setting, mGluR5 expression correlated with a decreased survival rate in patients with oral squamous cell carcinoma (Park et al., 2007) and an mGluR5 agonist increased tumor cell migration, invasion, and adhesion in human tongue cancer cells, an effect that was reversed by an mGluR5 antagonist (Park et al., 2007). On the contrary, in medulloblastoma, expression of mGluR4 was shown to be inversely related to tumor severity, spreading and recurrence (Iacovelli et al., 2006). Nevertheless, over-expression of mGluR4 was associated with poor prognosis in colorectal carcinoma (Chang et al., 2005) and their expression was identified in $68 \%$ of colorectal carcinomas, $50 \%$ of laryngeal carcinomas, and $46 \%$ of breast carcinomas (Julio-Pieper et al., 2011).

Concordant with the expression profile, pharmacological blockade of mGluR3 reduces cell proliferation and mitogen-activated protein kinase activation in cultured human glioma explants or glioma cell lines (D'Onofrio et al., 2003). Furthermore, systemic administration of the mGluR2/3 antagonist LY341495 inhibits the growth of glioma cells implanted either under the skin or inside the brain parenchyma of nude mice (Arcella et al., 2005). It is likely because of their neuroprotective role and the battery of trophic factors they induce that mGluR activation also stimulates glioma proliferation.

\section{Concluding remarks}

mGluRs play important neuromodulatory roles throughout the brain as such they are targets for therapeutic intervention for a number of psychiatric and neurological disorders including anxiety, depression, Parkinson's disease and schizophrenia.

Currently approved antipsychotic drugs have substantial extrapyramidal and metabolic side effects, but (beyond its high efficacy and ease of delivery) the advantage of use of mGluR ligands for the treatment of anxiety disorders is the lack of the commonest undesirable effects, which include alterations in prolactin levels, extrapyramidal symptoms, weight gain, glucose abnormalities, hypertension, sedation or Parkinsonian symptoms. The probability of a complete absence of adverse effects, however, does not seem to be very high because, as implied by the evidence compiled in this chapter, the implications of mGluR ligands toxicity are many and far-reaching.

mGluR1 selective antagonists showed efficacy in rodent models of anxiety, however, these compounds were associated with memory impairment that interrupted further development (Steckler et al., 2005a,b; Gravius et al., 2005). On the other hand, mGluR5 selective antagonists, which also has anxiolytic efficacy did not cause impairment in memory (Steckler et al., 2005a; Gravius et al., 2005).

As reported (Mezler et al 2010; Chaki et al 2010; Patil et al 2007), the latest developed allosteric group II mGluR agonists have efficacy in preclinical models of psychosis and anxiety, without involving any of the most frequent side effects associated with typical and atypical antipsychotics. Nevertheless, the ubiquity of mGluRs in peripheral tissues and the broad spectrum of possible side effects signify that the reported measurements are far from exhaustive. Consequently, some "silent" or long term unacceptable side effects on other target organs might be associated with mGluR agonist administration and should be considered. Endocrine alterations such as changes in LH, GH or oxytocin levels induced by group I mGluR ligands should be taken into consideration. Furthermore, fertility impairment and embryogenesis defects, immune deficits, sense function impairment and osteoporosis induced by group II mGluR activation are issues to be further studied. Finally, 
tumor development after mGluR ligand administration represents another possible risk to be further investigated. Hence, there is a need for screening and monitoring for all these possible problems, which are not considered in current clinical trials.

\section{References}

Aguilar, E.; Tena-Sempere, M. \& Pinilla, L. (2005). Role of excitatory amino acids in the control of growth hormone secretion. Endocrine, Vol.28, No.3, (December 2005), pp. 295-301, ISSN 1355-008X.

Akazawa, C.; Ohishi, H.; Nakajima, Y.; Okamoto, N.; Shigemoto, R.; Nakanishi, S. \& Mizuno, N. (1994). Expression of mRNAs of LAP4-sensitive metabotropic glutamate receptors (mGluR4, mGluR6, mGluR7) in the rat retina. Neurosci Lett, Vol.171, No.1-2, (April 1994), pp. 52-54, ISSN 0304-3940.

Akiba, Y.; Watanabe, C.; Mizumori, M. \& Kaunitz, J.D. (2009). Luminal L-glutamate enhances duodenal mucosal defense mechanisms via multiple glutamate receptors in rats. Am J Physiol Gastrointest Liver Physiol, Vol.297, No.4, (October 2009), pp. G781-G791, ISSN 0193-1857.

Anu, J.; Peeyush Kumar, T.; Nandhu, M.S. \& Paulose, C.S. (2010). Enhanced NMDAR1, NMDA2B and mGlu5 receptors gene expression in the cerebellum of insulin induced hypoglycaemic and streptozotocin induced diabetic rats. Eur J Pharmacol, Vol.630, No.1-3, (March 2010), pp. 61-68, ISSN 0014-2999.

Arcella, A.; Carpinelli, G.; Battaglia, G.; D’Onofrio, M.; Santoro, F.; Ngomba, R.T.; Bruno, V.; Casolini, P.; Giangaspero, F. \& Nicoletti, F. (2005). Pharmacological blockade of group II metabotropic glutamate receptors reduces the growth of glioma cells in vivo. Neuro Oncol, Vol.7, No.3, (July 2005), pp. 236-245, ISSN 0167-594X.

Boldyrev, A.A.; Kazey, V.I.; Leinsoo, T.A.; Mashkina, A.P.; Tyulina, O.V.; Johnson, P.; Tuneva, J.O.; Chittur, S.\& Carpenter, D.O. (2004). Rodent lymphocytes express functionally active glutamate receptors. Biochem Biophys Res Commun, Vol.324, No.1, (November 2004), pp. 133-139, ISSN 0006-291X.

Boldyrev, A.A.; Carpenter, D.O. \& Johnson, P. (2005). Emerging evidence for a similar role of glutamate receptors in the nervous and immune systems. J Neurochem, Vol.95, No.4, (November 2005), pp. 913-918, ISSN 0022-3042.

Bolea, C.; Mutel, V.; Rocher, J.P.; Bessis, A.S. \& Le Poul, E. (2004), inventors; Bolea, C.; Mutel, V.; Rocher, J.P.; Bessis, A.S.; Le Poul, E. \& Addex Pharmaceuticals SA, assignees. Novel aminopyridine derivatives as mGluR5 antagonists. World patent no. WO/2004/078728. 2004 Mar 4.

Bradbury, M.J.; Giracello, D.R.; Chapman, D.F.; Holtz, G.; Schaffhauser, H.; Rao, S.P.; Varney, M.A. \& Anderson, J.J. (2003). Metabotropic glutamate receptor 5 antagonist-induced stimulation of hypothalamic-pituitary-adrenal axis activity: interaction with serotonergic systems. Neuropharmacology, Vol.44, No.5, (April 2003), pp. 562-572, ISSN 0028-3908.

Bradbury, M.J.; Campbell, U.; Giracello, D.; Chapman, D.; King, C.; Tehrani, L.; Cosford, N.D.; Anderson, J.; Varney, M.A. \& Strack, A.M. (2005). Metabotropic glutamate receptor mGlu5 is a mediator of appetite and energy balance in rats and mice. $J$ Pharmacol Exp Ther, Vol.313, No.1, (April 2005), pp. 395-402, ISSN 0022-3565. 
Braga, V.A.; Antunes, V.R. \& Machado, B.H. (2006). Autonomic and respiratory responses to microinjection of L-glutamate into the commissural subnucleus of the NTS in the working heart-brainstem preparation of the rat. Brain Res, Vol.1093, No.1, (June 2006), pp. 150-160, ISSN 0006-8993.

Brandstätter, J.H.; Koulen, P. \& Wässle, H. (1998). Diversity of glutamate receptors in the mammalian retina. Vision Res, Vol.38, No.10, (May 1998), pp. 1385-1397, ISSN 00426989.

Brice, N.L.; Varadi, A.; Ashcroft, S.J.H. \& Molnar, E. (2002). Metabotropic glutamate and $\mathrm{GABA}_{\mathrm{B}}$ receptors contribute to the modulation of glucose-stimulated insulin secretion in pancreatic beta cells. Diabetologia, Vol.45, No.2, (February 2002), pp. 242-252, ISSN 0012-186X.

Bruno, V.; Battaglia, G.; Casabona, G.; Copani, A.; Caciagli, F. \& Nicoletti, F. (1998). Neuroprotection by glial metabotropic glutamate receptors is mediated by transforming growth factor-b. J Neurosci, Vol.18, No.23, (December 1998), pp. 95949600, ISSN 0270-6474.

Cabrera, O.; Jacques-Silva, M.C.; Speier, S.; Yang, S.; Köhler, M.; Fachado, A.; Vieira, E.; Zierath, J.R.; Kibbey, R.; Berman, D.M.; Kenyon, N.S.; Ricordi, C.; Caicedo, A. \& Berggren, P. (2008). Glutamate is a positive autocrine signal for glucagon release. Cell Metabolism, Vol.7, No.6, (June 2008), pp. 545-554, ISSN 1550-4131.

Cappuccio, I.; Verani, R.; Spinsanti, P.; Niccolini, C.; Gradini, R.; Costantino, S.; Nicoletti, F. \& Melchiorri, D. (2006). Context-dependent regulation of embryonic stem cell differentiation by mGlu4 metabotropic glutamate receptors. Neuropharmacology, Vol.51, No.3, (September 2006), pp. 606-611, ISSN 0028-3908.

Cartmell, J.; Perry, K.W.; Salhoff, C.R.; Monn, J.A. \& Schoepp, D.D. (2000). The potent, selective mGlu2/3 receptor agonist Ly 379268 increases extracellular levels of dopamine, 3,4-dihydroxyphenyl-acetic acid, homovanillic acid, and 5hydroxyindole- 3-acetic acid in the medial prefrontal cortex of the freely moving rat. J Neurochem, Vol.75, No.3, (September 2000), pp. 1147-1154, ISSN 0022-3042.

Caruso, C.; Bottino, M.C.; Pampillo, M.; Pisera, D.; Jaita, G.; Duvilanski, B.; Seilicovich, A. \& Lasaga, M. (2004). Glutamate induces apoptosis in anterior pituitary cells through group II metabotropic glutamate receptor activation. Endocrinology, Vol.145, No.10, (October 2004), pp. 4677-4684, ISSN 0013-7227.

Caruso, C.; Durand, D.; Watanobe, H. \& Lasaga, M. (2006). NMDA and group I metabotropic glutamate receptors activation modulates substance $\mathrm{P}$ release from the arcuate nucleus and median eminence. Neurosci Lett, Vol.393, No.1, (January 2006), pp. 60-64, ISSN 0304-3940.

Castro, J.B.; Hovis, K.R. \& Urban, N.N. (2007). Recurrent dendrodendritic inhibition of accessory olfactory bulb mitral cells requires activation of group I metabotropic glutamate receptors. J Neurosci, Vol.27, No.21, (May 2007), pp. 5664-5671, ISSN 0270-6474.

Celuch, S.M. \& García, M.C. (2002). Activation of spinal metabotropic glutamate receptors elicits cardiovascular responses in pentobarbital anesthetized rats. Naunyn Schmiedebergs Arch Pharmacol, Vol.366, No.4, (October 2002), pp. 343-349, ISSN 00281298. 
Chaki, S.; Yoshida, S. \& Okuyama, S. (2010). Targeting metabotropic glutamate receptors to develop novel antipsychotics. Japanese Journal of Psychopharmacology, Vol.30, No.5-6, (November 2010), pp. 207-213, ISSN 1340-2544.

Chang, H.J.; Yoo, B.C.; Lim, S.B.; Jeong, S.Y.; Kim, W.H. \& Park, J.G. (2005). Metabotropic glutamate receptor 4 expression in colorectal carcinoma and its prognostic significance. Clin Cancer Res, Vol.11, No.9, (May 2005), pp. 3288-95, ISSN 10780432 .

Chaudhari, N.; Pereira, E \& Roper, S.D. (2009). Taste receptors for umami: the case for multiple receptors. Am J Clin Nutr, Vol.90, No.3, (September 2009), pp. 738S-742S, ISSN 0002-9165.

Chenu, C. (2002). Glutamatergic innervations in bone. Microsc Res Tech, Vol.58, No.2, (July 2002), pp. 70-76, ISSN 1059-910X.

Chiocchetti, A.; Miglio, G.; Mesturini, R.; Varsaldi, F.; Mocellin, M.; Orilieri, E.; Dianzani, C.; Fantozzi, R.; Dianzani, U. \& Lombardi, G. (2006). Group I mGlu receptor stimulation inhibits activation-induced cell death of human T lymphocytes. $\mathrm{Br} \mathrm{J}$ Pharmacol, Vol.148, No.6, (July 2006), pp. 760-768, ISSN 0007-1188.

Choy, Y. (2007). Managing side effects of anxiolytics. Prim Psychiatry, Vol.14, No.7, pp. 68-76, ISSN 1082-6319.

Chu, Z. \& Moenter, M. (2005). Endogenous activation of metabotropic glutamate receptors modulates GABAergic transmission to gonadotropin-releasing hormone neurons and alters their firing rate: a possible local feedback circuit. J Neurosci, Vol.25, No.24, (June 2005), pp. 5740-5749, ISSN 0270-6474.

Ciccarelli, R.; D'Alimonte, I.; Ballerini, P.; et al. (2007). Molecular signaling mediating the protective effect of A1 adenosine and mGlu3 metabotropic glutamate receptor activation against apoptosis by oxygen/glucose deprivation in cultured astrocytes. Mol Pharmacol, Vol.71, No.5, (May 2007), pp. 1369-1380, ISSN 0026-895X.

Ciceroni, C.; Mosillo, P.; Mastrantoni, E.; Sale, P.; Ricci-Vitiani, L.; Biagioni, F.; Stocchi, F.; Nicoletti, F. \& Melchiorri, D. (2010). mGLU3 metabotropic glutamate receptors modulate the differentiation of SVZ-derived neural stem cells towards the astrocytic lineage. Glia, Vol.58, No.7, (May 2010), pp. 813-822, ISSN 0894-1491.

Conn, P.J. \& Niswender, C.M. (2006). mGluR7's lucky number. Proc Natl Acad Sci USA, Vol.103, No.2, (January 2006), pp. 251-252, ISSN 0027-8424.

Connaughton, V.P. (2005). The vertebrate retina, In: Glutamate Receptors in Peripheral Tissues, Gill, S. \& Pulido, O. eds, pp. 99-127, Kluwer Academic/Plenum Publishers, New York.

Crown, A.; Clifton, D.K. \& Steiner, R.A. (2007). Neuropeptide signaling in the integration of metabolism and reproduction. Neuroendocrinology, Vol.86, No.3, pp. 175-182, ISSN 0028-3835.

D'Onofrio, M.; Cuomo, L.; Battaglia, G.; Ngomba, R.T.; Storto, M.; Kingston, A.E.; Orzi, F.; De Blasi, A.; Di Iorio, P.; Nicoletti, F. \& Bruno, V. (2001). Neuroprotection mediated by glial group-II metabotropic glutamate receptors requires the activation of the MAP kinase and the phosphatidylinositol-3-kinase pathways. J Neurochem, Vol.78, No.3, (August 2001), pp. 435-45, ISSN 0022-3042. 
D’Onofrio, M.; Arcella, A.; Bruno, V.; Ngomba, R.T.; Battaglia, G.; Lombari, V.; Ragona, G.; Calogero, A. \& Nicoletti, F. (2003). Pharmacological blockade of mGlu2/3 metabotropic glutamate receptors reduces cell proliferation in cultured human glioma cells. J Neurochem, Vol.84, No.6, (March 2003), pp. 1288-1295, ISSN 00223042.

Debeljuk, L. \& Lasaga, M. (1999). Modulation of the hypothalamo-pituitary-gonadal axis and the pineal gland by neurokinin $\mathrm{A}$, neuropeptide $\mathrm{K}$ and neuropéptido gamma. Peptides, Vol.20, No.2, pp. 285-299, ISSN0196-9781.

Dewing, P.; Boulware, M.I.; Sinchack, K.; Christensen, A.; Mermelstein, P.G. \& Micevych, P. (2007). Membrane ER $\alpha$ interacts with mGluR1a to modulate female sexual receptivity. J Neurosci, Vol.27, No.35, (August 2007), pp. 9294-9300, ISSN 0270-6474.

Do, S.H.; Yun, H.S.; Jeong, W.I.; Jeong, D.H.; Ki, M.R.; et al. (2007). Up-regulation of metabotropic glutamate receptor 3 (mGluR3) in rat fibrosis and cirrhosis model of persistent hypoxic condition. Mol Cell Biochem, Vol.294, No.1-2, (January 2007), pp. 189-196, ISSN 0300-8177.

Doleviczényi, Z.; Halmos, G.; Répássy, G.; Vizi, E.S.; Zelles, T. \& Lendvai, B. (2005). Cochlear dopamine release is modulated by group II metabotropic glutamate receptors via GABAergic neurotransmission. Neurosci Lett, Vol.385, No2. (September 2005), pp. 93-98, ISSN 0304-3940.

Dröge, W.; Eck, H.P.; Betzler, .; Schlag, P.; Drings, P. \& Ebert, W. (1988). Plasma glutamate concentration and lymphocyte activity. J Cancer Res Clin Oncol, Vol.114, No.2, pp. 124-128, ISSN 0171-5216.

Dumalska, I.; Wu, M.; Morozova, E.; Liu, R.; van den Pol, A. \& Alreja, M. (2008). Excitatory effects of the puberty-initiating peptide kisspeptin and group I metabotropic glutamate receptor agonists differentiate two distinct subpopulations of gonadotropin-releasing hormone neurons. J Neurosci, Vol.28, No.32, (August 2008), pp. 8003-8013, ISSN 0270-6474.

Durand, D.; Caruso, C.; Carniglia, L. \& Lasaga, M. (2010). Metabotropic glutamate receptor 3 activation prevents nitric oxide-induced death in cultured rat astrocytes. $J$ Neurochem, Vol.112, No.2, (January 2010), pp. 420-433, ISSN 0022-3042.

Fallarino, F.; Volpi, C.; Fazio, F.; Notartomaso, S.; Vacca, C.; Busceti, C.; Bicciato, S.; Battaglia, G.; Bruno, V.; Pucetti, P.; Fioretti, M.C.; Nicoletti, F.; Grohmann, U. \& Di Marco, R. (2010). Metabotropic glutamate receptor-4 modulates adaptive immunity and restrains neuroinflammation. Nat Med, Vol.16, No.8, (August 2010), pp. 897902, ISSN 1078-8956.

Ferrarese, C.; Aliprandi, A.; Tremolizzo, L.; Stanzani, L.; De Micheli, A.; Dolara, A. \& Frattola, L. (2001). Increased glutamate in CSF and plasma of patients with HIV dementia. Neurology, Vol.57, No.4, (August 2001), pp. 671-675, ISSN 0028-3878.

Foley, C.M.; Vogl, H.W.; Mueller, P.J.; Hay, M. \& Hasser, E.M. (1999). Cardiovascular response to group I metabotropic glutamate receptor activation in NTS. Am J Physiol, Vol.276, No.5 Pt 2, (May 1999), pp. R1469-R1478, ISSN 0002-9513.

Foreman, M.A.; Gu, Y.; Howl, J.D.; Jones, S. \& Publicover, S.J. (2005). Group III metabotropic glutamate receptor activation inhibits $\mathrm{Ca} 2+$ influx and nitric oxide synthase activity 
in bone marrow stromal cells. J Cell Physiol, Vol.204, No.2, (August 2005), pp. 704713, ISSN 0021-9541.

Friedman, R.A.; Van Laer, L.; Huentelman, M.J.; Sheth, S.S.; Van Eyken, E.; Corneveaux, J.J.; Tembe, W.D.; Halperin, R.F.; Thorburn, A.Q.; Thys, S.; et al. (2009). GRM7 variants confer susceptibility to age-related hearing impairment. Hum Mol Genet, Vol.18, No.4, (February 2009), pp. 785-796, ISSN 0964-6906.

Frisby, C.L.; Mattsson, J.P.; Jensen, J.M.; Lehmann, A.; Dent, J. \& Blackshaw, L.A. (2005). Inhibition of transient lower esophageal sphincter relaxation and gastroesophageal reflux by metabotropic glutamate receptor ligands. Gastroenterology, Vol.129, No.3, (September 2005), pp. 995-1004, ISSN 0016-5085.

Gerber, U. (2003). Metabotropic glutamate receptors in vertebrate retina. Doc Ophthalmol, Vol.106, No.1, (January 2003), pp. 83-87, ISSN 0012-4486.

Gill, S.S.; Pulido, O.M.; Mueller, R.W. \& McGuire, P.F. (1999). Immunochemical localization of the metabotropic glutamate receptors in the rat heart. Brain Res Bull, Vol.48, No.2, (January 1999), pp. 143-146, ISSN 0361-9230.

Gill, S.S. \& Pulido, O.M. (2001). Glutamate receptors in peripheral tissues: current knowledge, future research, and implications for toxicology. Toxicol Pathol, Vol.29, No.2, (March-April 2001), pp. 208-223, ISSN 0192-6233.

Gill, S.; Veinot, J.; Kavanagh, M. \& Pulido, O. (2007). Human heart glutamate receptors implications for toxicology, food safety, and drug discovery. Toxicol Pathol, Vol.35, No.3, pp. 411-417, ISSN 0192-6233.

Gill, S.; Barker, M. \& Pulido, O. (2008). Neuroexcitatory targets in the female reproductive system of the nonhuman primate (Macaca fascicularis). Toxicol Pathol, Vol.36, No.3, pp. 478-84, ISSN 0192-6233.

Gravius, A.; Pietraszek, M.; Schäfer, D.; Schmidt, W.J. \& Danysz, W. (2005). Effects of mGlu1 and mGlu5 receptor antagonists on negatively reinforced learning. Behav Pharmacol, Vol.16, No.2, (March 2005), pp. 113-121, ISSN 0955-8810.

Gu, G.; Varoqueaux, F. \& Simerly, R.B. (1999). Hormonal regulation of glutamate receptor gene expression in the anteroventral periventricular nucleus of the hypothalamus. $J$ Neurosci, Vol.19, No.8, (April 1999), pp. 3213-3222, ISSN 0270-6474.

$\mathrm{Gu}$, Y. \& Publicover, S.J. (2000). Expression of functional metabotropic glutamate receptors in primary cultured rat osteoblasts. Cross-talk with N-methyl-D-aspartate receptors. J Biol Chem, Vol.275, No.44, (November 2000), pp. 34252-34259, ISSN 0021-9258.

Hartveit, E.; Brandstätter, J.H.; Enz, R. \& Wässle, H. (1995). Expression of the mRNA of seven metabotropic glutamate receptors (mGluR1 to 7) in the rat retina. An in situ hybridization study on tissue sections and isolated cells. Eur J Neurosci, Vol.7, No.7, (July 1995), pp. 1472-1483, ISSN 0953-816X.

Hendricson, A.W \& Guth, P.S. (2002). Signal discrimination in the semicircular canals: a role for group I metabotropic glutamate receptors. Neuroreport, Vol.13, No.14, (October 2002), pp. 1765-1768, ISSN 0959-4965.

Heuss, C.; Scanziani, M.; Gahwiler, B.H.; et al. (1999). G-protein independent signaling mediated by metabotropic glutamate receptors. Nat Neurosci, Vol.2, No.12, (December 1999), pp. 1070-1077, ISSN 1097-6256. 
Hinoi, E.; Fujimori, S.; Nakamura, Y. \& Yoneda, Y. (2001). Group III metabotropic glutamate receptors in rat cultured calvarial osteoblasts. Biochem Biophys Res Commun, Vol.281, No.2, (February 2001), pp. 341-346, ISSN 0006-291X.

Iacovelli, L.; Arcella, A.; Battaglia, G.; Pazzaglia, S.; Aronica, E.; Spinsanti, P.; Caruso, A.; De Smaele, E.; Saran, A.; Gulino, A.; et al. (2006). Pharmacological activation of mGlu4 metabotropic glutamate receptors inhibits the growth of medulloblastomas. $J$ Neurosci, Vol.26, No.32, (August 2006), pp. 8388-8397, ISSN 0270-6474.

Iremonger, K.J.; Constantin, S.; Liu, X. \& Herbison, A.E. (2010). Glutamate regulation of GnRH neuron excitability. Brain Res, Vol.1364, (December 2010), pp. 35-43, ISSN 0006-8993.

Jackson, E.K.; Branch, R.A.; Margoius, H.S. \& Oates, J.A. (1985). Physiological functions of the renal prostaglandin, renin and kallikrein systems, In: The Kidney-Physiology and Pathology, Seldin, D.W. \& Giebisch, G. (ed), pp. 613-644, Raven Press, New York.

Jesse, C.R.; Wilhelm, E.A.; Bortolatto, C.F.; Savegnano, L. \& Nogueira, C.W. (2009). Selective blockade of mGlu5 metabotropic glutamate receptors is hepatoprotective against fulminant hepatic failure induced by lipopolysaccharide and D-galactosamine in mice. J Appl Toxicol, Vol.29, No.4, (May 2009), pp. 323-329, ISSN 0260-437X.

Johnson, M.P.; Kelly, G. \& Chamberlain, M. (2001). Changes in rat serum corticosterone after treatment with metabotropic glutamate receptor agonists or antagonists. J Neuroendocrinology, Vol.13, No.8, (August 2001), pp. 670-677, ISSN 0953-8194.

Johnson, M.P. \& Chamberlain, M. (2002). Modulation of stress-induced and stimulated hyperprolactinemia with the group II metabotropic glutamate receptor selective agonist, Ly 379268. Neuropharmacology, Vol.43, No.5, (October 2002), pp. 799-808, ISSN 0028-3908.

Jones, N.M.; Beart, P.M.; Monn, J.A \& Widdop, R.E. (1999). Type I and II metabotropic glutamate receptor mediate depressor and bradycardic actions in the nucleus of the solitary tract of anaesthetized rats. Eur J Pharmacol, Vol.380, No.2-3, (September 1999), pp. 129-135, ISSN 0014-2999.

Julio-Pieper, M.; Hyland, N.P.; Bravo, J.A.; Dinan, T.G. \& Cryan, J.F. (2010). A novel role for metabotropic glutamate receptor 7: modulation of faecal water content and colonic electrolyte transport in the mouse. Br J Pharmacol, Vol.160, No.2, (May 2010), pp. 367-375, ISSN 0007-1188.

Julio-Pieper, M.; Flor, P.J.; Dinan, T.G. \& Cryan, J.F. (2011). Exciting times beyond the brain: metabotropic glutamate receptors in peripheral and non-neural tissues. Pharmacological Reviews, Vol.63, No.1, (), pp. 35-58, ISSN 0031-6997.

Kingston, A.E.; O’Neill, M.J.; Lam, A.; Bales, K.R.; Monn, J.A. \& Schoepp, D.D. (1999). Neuroprotection by metabotropic glutamate receptor agonists: LY354740, LY379268 and LY389795. Eur J Pharmacol, Vol.377, No.2-3, (July 1999), pp. 155-165, ISSN 00142999.

Kleinlogel, S.; Oestreicher, E.; Arnold, T.; Ehrenberger, K. \& Felix, D. (1999). Metabotropic glutamate receptors group I are involved in cochlear neurotransmission. Neuroreport, Vol.10, No.9, (June 1999), pp. 1879-1882, ISSN 0959-4965. 
Koulen, P.; Kuhn, R.; Wässle, H. \& Brandstätter, J.H. (1997). Group I metabotropic glutamate receptors mGluR1_ and mGluR5a: localization in both synaptic layers of the rat retina. J Neurosci, Vol.17, No.6, (March 1997), pp. 2200-2211, ISSN 0270-6474.

Koulen, P.; Kuhn, R.; Wässele, H. \& Brandstätter, J.H. (1999). Modulation of intracellular calcium concentration in photoreceptor terminals by a presynaptic metabotropic glutamate receptor. Proc Natl Acad Sci USA, Vol.96, No.7, (August 1999), pp. 99099914, ISSN 0027-8424.

Kuo, J.; Hariri, O.R.; Bondar, G.; Ogi, J. \& Micevych, P. (2009). Membrane oestrogen receptor-alpha interacts with metabotropic glutamate receptor type 1a to mobilize intracellular calcium in hypothalamic astrocytes. Endocrinology, Vol.150, No.3, (March 2009), pp. 1369-1376, ISSN 0013-7227.

Lang, C.H. \& Ajmal, M. (1995). Metabolic, hormonal, and hemodynamic changes induced by metabotropic excitatory amino acid agonist (1S, 3R)-ACPD. Am J Physiol, Vol.268, No.4 Pt 2, (April 1995), pp. 1026-1033, ISSN 0002-9513.

Larzabal, A.; Losada, J.; Mateos, J.M.; Benítez, R.; Garmilla, I.J.; Kuhn, R.; Grandes, P. \& Sarría, R. (1999). Distribution of the group II metabotropic glutamate receptors (mGluR2/3) in the enteric nervous system of the rat. Neurosci Lett, Vol.276, No.2, (December 1999), pp. 91-94, ISSN 0304-3940.

Lavreysen, H. \& Dautzenberg, F.M. (2008). Therapeutic potential of group III metabotropic glutamate receptors. Curr Med Chem, Vol.15, No.7, pp. 671-384, ISSN 0929-8673.

Liu, M. \& Kirchgessner, A.L. (2000). Agonist- and reflex-evoked internalization of metabotropic glutamate receptor 5 in enteric neurons. J Neurosci, Vol.20, No.9, (May 2000), pp. 3200-3205, ISSN 0270-6474.

Lopez, F.J.; Donoso, A.O. \& Negro-Vilar, A. (1992). Endogenous excitatory amino acids and glutamate receptor subtypes involved in the control of hypothalamic luteinizing hormone-releasing hormone secretion. Endocrinology, Vol.130, No.4, (April 1992), pp. 1986-1992, ISSN 0013-7227.

Marin, Y.E. \& Chen, S. (2004). Involvement of metabotropic glutamate receptor 1, a G protein coupled receptor, in melanoma development. J Mol Med, Vol.82, No.11, (November 2004), pp. 735-749, ISSN 0946-2716.

Meeker, R.B.; Greenwood, R.S. \& Hayward, J.N. (1994). Glutamate receptors in the rat hypothalamus and pituitary. Endocrinology, Vol.134, No.2, (February 1994), pp. 624629, ISSN 0013-7227.

Mezler, M.; Geneste, H.; Gault L. \& Marek, G.J. (2010). LY-2140023, a prodrug of the group II metabotropic glutamate receptor agonist LY-404039 for the potential treatment of schizophrenia. Curr Opin Investig Drugs, Vol.11, No.7, (July 2010), pp.833-845, ISSN 1472-4472.

Micevych, P.; Bondar, G. \& Kuo, J. (2010). Estrogen actions on neuroendocrine glia. Neuroendocrinology, Vol.91, No.3, pp. 211-222, ISSN ISSN 0028-3835.

Miglio, G.; Varsaldi, F.; Dianzani, C.; Fantozzi, R. \& Lombardi, G. (2005). Stimulation of group I metabotropic glutamate receptors evokes calcium signals and c-jun and cfos gene expression in human T cells. Biochem Pharmacol, Vol.70, No.2, (July 2005), pp 189-199, ISSN 0006-2952. 
Mitsukawa, K.; Mombereau, C.; Lötscher, E.; Uzunov, D.P.; van der Putten, H.; Flor, P.J. \& Cryan, J.F. (2006). Metabotropic glutamate receptor subtype 7 ablation causes dysregulation of the HPA axis and increases hippocampal BDNF protein levels: implications for stress-related psychiatric disorders. Neuropsychopharmacology, Vol.31, No.6, (June 2006), pp. 1112-1122, ISSN 0893-133X.

Moore-Morris, T.; Varrault, A.; Mangoni, M.E.; Le Digarcher, A.; Negre, V.; Dantec, C.; Journot, L.; Nargeot, J. \& Couette, B. (2009). Identification of potential pharmacological targets by analysis of the comprehensive $G$ protein-coupled receptor repertorie in the four cardiac chambers. Mol Pharmacol, Vol.75, No.5, (May 2009), pp. 1108-1116, ISSN 0026-895X.

Moreno, J.L.; Sealfon, S.C. \& González-Maeso, J. (2009). Group II metabotropic glutamate receptors and schizophrenia. Cell Mol Life Sci, Vol.66, No.23, (December 2009), pp. 3777-3785, ISSN 1420-682X.

Morimoto, R.; Uehara, S.; Yatsushiro, S.; Juge, N.; Hua, Z.; Senoh, S.; Echigo, N.; Hayashi, M.; Mizoguchi, T.; Ninomiya, T.; et al. (2006). Secretion of L-glutamate from osteoclasts through transcytosis. EMBO J, Vol.25, No.18, (September 2006), pp. 4175-4186, ISSN 0261-4189.

Morsette, D.J.; Sidorowicz, H. \& Sladek, C.D. (2001). Role of metabotropic glutamate receptors in vasopressin and oxytocin release. Am J Physiol Regul Integr Comp Physiol, Vol.281, No.2, (August 2001), pp. R452-R458, ISSN0363-6119.

Mueller, R.W.; Gill, S.S. \& Pulido, O.M. (2003). The monkey (Macaca fascicularis) heart neural structures and conducting system: an immunochemical study of selected neural biomarkers and glutamate receptors. Toxicol Pathol, Vol.31, No.2, (MarchApril 2003), pp. 227-234, ISSN 0192-6233.

Nagy, G.M.; Bodnár, I.; Bánky, Z. \& Halász, B. (2005). Control of prolactin secretion by excitatory amino acids. Endocrine, Vol.28, No.3, (December 2005), pp. 303-308, ISSN 1355-008X.

Nakamura, E.; Hasumura, M.; San Gabriel, A.; Uneyama, H. \& Torii, K. (2010). New frontiers in gut nutrient sensor research: luminal glutamate-sensing cells in rat gastric mucosa. J Pharmacol Sci, Vol.112, No.1, (January 2010), pp. 13-18, ISSN 13478613.

Nasser, Y.; Keenan, C.M.: Ma, A.C.; McCafferty, D.M. \& Sharkey, K.A. (2007). Expression of a functional metabotropic glutamate receptor 5 on enteric glia is altered in states of inflammation. Glia, Vol.55, No.8, (June 2007), pp. 859-872, ISSN 0894-1491.

Nicoletti, F.; Battaglia, G.; Storto, M.; Ngomba, R.T.; Iacovelli, L.; Arcella, A.; Gradini, R.; Sale, P.; Rampello, L.; De Vita, T.; Di Marco, R.; Melchiorri, D. \& Bruno, V. (2007). Metabotorpic glutamate receptors: Beyond the regulation of synaptic transmission. Psychoneuroendocrinology, Vol.32, No1, (August 2007), pp. S40-S45, ISSN 0306-4530.

Ninan, P.T.; Cole, J.O. \& Yonkers, K.A. (1998). Nonbenzodiazepine anxiolytics. In: Textbool of Psychopharmacology, Schatzberg, A.F. \& Nemeroff, C.B. (eds.), pp. 287-300, American Psychiatric Press, Washington, DC.

Nolte, C.M. \& Meredith, M. (2005). mGluR2 activation of medial amygdala input impairs vomeronasal organ-mediated behavior. Physiol Behav, Vol.86, No.3, (October 2005), pp. 314-323, ISSN 0031-9384. 
Noyes, R. Jr. (1985): Beta-adrenergic blocking drugs in anxiety and stress. Psychiatr Clin North Am, Vol.8, No.1, (March 1985), pp. 119-132, ISSN 0193-953X.

Olney, J.W. (1969). Brain lesions, obesity, and other disturbances in mice treated with monosodium glutamate. Science, Vol.164, No.880, (May 1969), pp. 719-721, ISSN 0193-4511.

Pabst, H. \& Redecker, P. (1999). Interstitial glial cells of the gerbil pineal gland display immunoreactivity for the metabotropic glutamate receptors mGluR2r3 and mGluR5. Brain Res, Vol.838, No.1-2, (August 1999), pp. 60-68, ISSN 0006-8993.

Pacheco, R.; Ciruela, F.; Casadó, V.; Mallol, J.; Gallart, T.; Lluis, C. \& Franco, R. (2004). Group I metabotropic glutamate receptors mediate a dual role of glutamate in $\mathrm{T}$ cell activation. J Biol Chem, Vol.279, No.32, (August 2004), pp. 33352-33358, ISSN 0021-9258.

Pacheco, R.; Oliva, H.; Martinez-Navío, J.M.; Climent, N.; Ciruela, F.; Gatell, J.M.; Gallart, T.; Mallol, J.; Lluis, C. \& Franco, R. (2006). Glutamate released by dendritic cells as a novel modulator of T cell activation. J Immunol, Vol.177, No.10, (November 2006), pp. 6695-6704, ISSN 0022-1767.

Pacheco, R.; Gallart, T.; Lluis, C. \& Franco, R. (2007). Role of glutamate on T-cell mediated immunity. J Neuroimmunol, Vol.185, No.1-2, (April 2007), pp. 9-19, ISSN 0165-5728.

Pampillo, M.; Diaz, M.C.; Duvilanski, B.H.; Rettori, V.; Seilicovich, A. \& Lasaga, M. (2001). Differential effects of glutamate agonists and D-aspartate on oxytocin release from hypothalamus and posterior pituitary of male rats. Endocrine, Vol.15, No.3, (August 2001), pp. 309-315, ISSN 1355-008X.

Pampillo, M.; Scimonelli, T.; Duvilanski, B.H.; Celis, M.E.; Seilicovich, A. \& Lasaga, M. (2002a). The activation of metabotropic glutamate receptors differentially affects GABA and alpha-melanocyte stimulating hormone release from the hypothalamus and the posterior pituitary of male rats. Neurosci Lett, Vol.327, No.2, (July 2002), pp. 95-98, ISSN 0304-3940.

Pampillo, M.; Theas, S.; Duvilanski, B.; Seilicovich, A. \& Lasaga, M. (2002b). Effect of ionotropic and metabotropic glutamate agonists and D-aspartate on prolactin release from anterior pituitary cells. Exp Clin Endocrinol Diabetes, Vol.110, No.3, (May 2002), pp. 138-144, ISSN 0947-7349.

Park, S.Y.; Lee, S.A.; Han, I.H.; Yoo, B.C.; Lee, S.H.; Park, J.Y.; Cha, I.H.; Kim, J. \& Choi, S.W. (2007). Clinical significance of metabotropic glutamate receptor 5 expression in oral squamous cell carcinoma. Oncol Rep, Vol.17, No.1, (January 2007), pp. 81-87, ISSN 1021-335X.

Patil, S.T.; Zhang, L.; Martenyi, F.; Lowe, S.L.; Jackson, K.A.; Andreev, B.V.; Avedisova, A.S.; Bardenstein, L.M.; Gurovich, I.Y.; Morozova, M.A.; Mosolov, S.N.; Neznanov, N.G.; Reznik, A.M.; Smulevich, A.B.; Tochilov, V.A.; Johnson, B.G.; Monn, J.A. \& Schoepp, D.D. (2007). Activation of mGlu2/3 receptors as a new approach to treat schizophrenia: a randomized Phase 2 clinical trial. Nat Med, Vol.13, No.9, (September 2007), pp. 1102-1107, ISSN 1078-8956.

Rastaldi,M.P.; Armelloni,S.; Berra, S.; Calvaresi, N.; Corbelli, A.; Giardino, L.A.; Li, M.; Wang, G.Q.; Fornasieri, A.; Villa, A.; Heikkila, E.; Soliymani, R.; Boucherot, A.; Cohen, C.D.; Kretzler, M.; Nitsche, A.; Ripamonti, M.; Malgaroli, A.; Pesaresi, M.; 
Forloni, G.L.; Schlöndorff, D.; Holthofer, H. \& D'Amico, G. (2006). Glomerular podocytes contain neuron-like functional synaptic vesicles. FASEB J, Vol.20, No.7, (May 2006), pp. E88-E98, ISSN 0892-6638.

Rezzani, R.; Corsetti, G.; Rodella, L.; Angoscini, P.; Lonati, C.\& Bianchi, R. (2003). Cyclosporine-A treatment inhibits the expression of metabotropic glutamate receptors in rat thymus. Acta Histochem, Vol.105, No.1, pp. 81-87, ISSN 0065-1281.

Safieddine, S. \& Eybalin, M. (1995). Expression of mGluR1 alpha mRNA receptor in rat and guinea pig cochlear neurons. Neuroreport, Vol.7, No.1, (December 1995), pp. 193196, ISSN 0959-4965.

San Gabriel, A.M.; Maekawa, T.; Uneyama, H.; Yoshie, S. \& Torii, K. (2007). mGluR1 in the fundic glands of rat stomach. FEBS Lett, Vol.581, No.6, (March 2007), pp. 1119-1123, ISSN 0014-5793.

Scaccianoce, S.; Matrisciano, F.; Del Bianco, P.; Caricasole, A.; Di Giorgi Gerevini, V.; Cappuccio, I.; Melchiorri, D.; Battaglia, G. \& Nicoletti, F. (2003). Endogenous activation of group-II metabotropic glutamate receptors inhibits the hypothalamicpituitary- adrenocortical axis. Neuropharmacology, Vol.44, No.5, (April 2003), pp. 555-561, ISSN 0028-3908.

Schlumberger, C.; Pietraszek, M.; Gravius A.; Klein, K.U.; Greco S.; Moré L. \& Danysz, W. (2009). Comparison of the $\mathrm{mGlu(5)}$ receptor positive allosteric modulator ADX47273 and the mGlu(2/3) receptor agonist LY354740 in tests for antipsychoticlike activity. Eur J Pharmacol, Vol.623, No.1-3, (November 2009), pp. 73-83, ISSN 0014-2999.

Schoepp, D.D. (2001). Unveiling the functions of presynaptic metabotropic glutamate receptors in the central nervous system. J Pharmacol Exp Ther, Vol.299, No.1, (October 2001), pp. 12-20, ISSN 0022-3565.

Schoepp, D.D.; Wright, R.A.; Levine, L.R.; Gaydos, B. \& Potter, W.Z. (2003). LY354740, an mGlu2/3 receptor agonist as a novel approach to treat anxiety/stress. Stress, Vol.6, No.3, (September 2003), pp. 189-197, ISSN 1025-3890.

Schoepp, D.D. (2004). Case study: utility of metabotropic glutamate agonists in psychiatric illness. $5^{\text {th }}$ World Conference on Stress, Abs 120.

Schrader, L.A. \& Tasker, J.G. (1997a). Modulation of multiple potassium currents by metabotropic glutamate receptors in neurons of the hypothalamic supraoptic nucleus. J Neurophysiol, Vol. 78, No.6, (December 1997), pp. 3428-3437, ISSN 00223077.

Schrader, L.A. \& Tasker, J.G. (1997b). Presynaptic modulation by metabotropic glutamate receptors of excitatory and inhibitory synaptic inputs to hypothalamic magnocellular neurons. J Neurophysiol, Vol.77, No.2, (February 1997), pp. 527-536, ISSN 0022-3077.

Seeman, P.; Caruso, C. \& Lasaga, M. (2008). Dopamine partial agonist actions of the glutamate receptor agonists Ly 354,740 and Ly 379,268. Synapse, Vol.62, No.2, (February 2008), pp. 154-158, ISSN 0887-4476.

Spooren, W.P.J.M.; Vassout, A.; Neijt, H.C.; Kuhn, R.; Gasparini, F.; Roux, S.; Porsolt, R.D. \& Gentsch, C. (2000). Anxiolytic-like effects of the prototypical metabotropic 
glutamate receptor 5 antagonist 2-methyl-6-(phenylethynyl)pyridine in rodents. J Pharmacol Exp Ther, Vol.295, No.3, (December 2000), pp. 1267-1275, ISSN 0022-3565.

Stahl, S.M. (2000). Essential psychopharmacology: neuroscientific basis and practical applications. $2^{\text {nd }}$ ed. Cambridge, MA: Cambridge University Press.

Steckler, T.; Lavreysen, H.; Oliveira, A.M., Aerts, N.; Craenendonck, H.; Prickaerts, J.; Megens, A. \& Lesage, A.S. (2005a). Effects of mGlu1 receptor blockade on anxietyrelated behavior in the rat lick suppression test. Psychopharmacol, Vol.179, No.1, (April 2005), pp. 198-206, ISSN 0033-3158.

Steckler, T.; Oliveira, A.M.; Van Dyck, C.; Craenendonck, H.; Mateus, A.M.; Langlois, X., Lesage, A.S. \& Prickaerts, J. (2005b). Metabotropic glutamate receptor 1 blockade impairs acquisition and retention in a spatial Water maze task. Behav Brain Res, Vol.164, No.1, (October 2005), pp. 52-60, ISSN 0166-4328.

Stepulak, A.; Luksch, H.; Gebhardt, C.; Uckermann, O.; Marzahn, J.; Sifringer, M.; Rzeski, W.; Staufner, C.; Brocke, K.S.; Turski, L. \& Ikonomidou, C. (2009). Expression of glutamate receptor subunits in human cancers. Histochem Cell Biol, Vol.132, No.4, (October 2009), pp. 435-445, ISSN 0948-6143.

Storto, M.; De Grazia, U.; Knöpfel, T.; Canonico, P.L.; Copani, A.; Richelmi, P.; Nicoletti, F. \& Vairetti, M. (2000a). Selective blockade of mGluR5 metabotropic glutamate receptors protects rat hepatocytes against hypoxic damage. Hepatology, Vol.31, No.3, (March 2000), pp. 649-655, ISSN 0270-9139.

Storto, M.; de Grazia, U.; Battaglia, G.; Felli, M.P.; Maroder, M.; Gulino, A.; Ragona, G.; Nicoletti, F.; Screpanti, I.; Frati, L.; et al. (2000b). Expression of metabotropic glutamate receptors in murine thymocytes and thymic stromal cells. $J$ Neuroimmunol, Vol.109, No.2, (September 2000), pp. 112-120, ISSN 0165-5728.

Storto, M.; Sallese, M.; Salvatore, L.; Poulet, R.; Condorelli, D.F.; Dell'Albani, P.; Marcello, M.F.; Romeo, R.; Piomboni, P.; Barone, N.; Nicoletti, F. \& De Blasi, A. (2001). Expression of metabotropic glutamate receptors in the rat and human testis. $J$ Endocrinol, Vol.170, No.1, (July 2001), pp. 71-78, ISSN 0022-0795.

Storto, M.; Ngomba, R.T.; Battaglia, G.; Freitas, I.; Griffini, P.; et al. (2003). Selective blockade of mGlu5 metabotropic glutamate receptors is protective against acetaminophen hepatotoxicity in mice. J Hepatol, Vol.38, No.2, (February 2003), pp. 179-187, ISSN 0168-8278.

Storto, M.; Battaglia, G.; Gradini, R.; Bruno, V.; Nicoletti, F. \& Vairetti, M. (2004). Mouse hepatocytes lacking mGlu5 metabotropic glutamate receptors are less sensitive to hypoxic damage. Eur J Pharmacol, Vol.497, No.1, (August 2004), pp. 25-27, ISSN 0014-2999.

Storto, M.; Capobianco, L.; Battaglia, G.; Molinaro, G.; Gradini, R.; et al. (2006). Insulin secretion is controlled by mGlu5 metabotropic glutamate receptors. Mol Pharmacol, Vol.69, No.4, (April 2006), pp. 1234-1241, ISSN 0026-895X.

Sureda, F.; Copani, A.; Bruno, V.; Knopfel, T.; Meltzger, G. \& Nicoletti, F. (1997). Metabotropic glutamate receptor agonists stimulate poly-phosphoinositide hydrolysis in primary cultures of rat hepatocytes. Eur J Pharmacol, Vol.338, No.2, (November 1997), pp. R1-R2, ISSN 0014-2999. 
Tong, Q.; Quedraogo, R. \& Kirchgessner, A.L. (2002). Localization and function of Group III metabotropic glutamate receptors in rat pancreatic islets. Am J Physiol Endocrinol Metab, Vol.282, No.6, (June 2002), pp. 1324-1333, ISSN 0193-1849.

Tong, Q. \& Kirchgessner, A.L. (2003). Localization and function of metabotropic glutamate receptor 8 in the enteric nervous system. Am J Physiol Gastrointest Liver Physiol, Vol.285, No.5, (November 2003), pp. G992-G1003, ISSN 0193-1857.

Toyono, T.; Kataoka, S.; Seta, Y.; Shigemoto, R. \& Toyoshima, K. (2007). Expression of group II metabtoropic glutamate receptors in rat gustatory papillae. Cell Tissue Res, Vol.328, No.1, (April 2007), pp. 57-63, ISSN 0302-766X.

Tsuchihashi, T.; Liu, Y.; Kagiyama, S.; Matsumura, K.; Abe, I. \& Fujishima, M. (2000). Metabotropic glutamate receptor subtypes involved in cardiovascular regulation in the rostral ventrolateral medulla of rats. Brain Res Bull, Vol.52, No.4, (July 2000), pp. 279-283, ISSN 0361-9230.

Üçok, A. \& Gaebel, W. (2008). Side effects of atypical antipsychotics: a brief overview. World Psychiatry, Vol.7, No.1, (February 2008), pp. 58-62, ISSN 1723-8617.

Uehara, S.; Muroyama, A.; Echigo, N.; Morimoto, R.; Otsuka, M.; Yatsushiro, S. \& Moriyama, Y. (2004). Metabotropic glutamate receptor type 4 is involved in autoinhibitory cascade for glucagon secretion by $\alpha$-cells of islets of Langerhans. Diabetes, Vol.53, No.4, (April 2004), pp. 998-1006, ISSN 0012-1797.

Van den Pol, A.; Wuarin, J.P. \& Dudek, F.E. (1990). Glutamate, the dominant excitatory transmitter in neuroendocrine regulation. Science, Vol.250, No.4985, (November 1990), pp. 1276-1278, ISSN 0193-4511.

Viard, E. \& Sapru, H.N. (2002). Cardiovascular responses to activation of metabotropic glutamate receptors in the nTS of the rat. Brain Res, Vol.952, No.2, (October 2002), pp. 308-321, ISSN 0006-8993.

Wang, L.; Hinoi, E.; Takemori, A.; Takarada, T. \& Yoneda, Y. (2005). Abolition of chondral mineralization by group III metabotropic glutamate receptors expressed in rodent cartilage. Br J Pharmacol, Vol.146. No.5, (November 2005), pp. 732-743, ISSN 00071188.

Wang, L.; Hinoi, E.; Takemori, A.; Nakamichi, N. \& Yoneda, Y. (2006). Glutamate inhibits chondral mineralization through apoptotic cell death mediated by retrograde operation of the cystine/glutamate antiporter. J Biol Chem, Vol.281, No.34, (August 2006), pp. 24553-24565, ISSN 0021-9258.

Wright, C.L. \& McCarthy, M.M. (2009). Prostaglandin E2-induced masculinization of brain and behavior requires protein kinase A, AMPA/kainate, and metabotropic glutamate receptor signaling. J Neurosci, Vol.29, No.42, (October 2009), pp. 1327413282, ISSN 0270-6474.

Yamada, H.; Yatsushiro, S.; Ishio, S.; Hayashi, M.; Nishi, T.; Yamamoto, A.; Futai, M.; Yamaguchi, A. \& Moriyama, Y. (1998). Metabotropic glutamate receptors negatively regulate melatonin synthesis in rat pinealocytes. J Neurosci, Vol.18, No.6, (March 1998), pp. 2056-2062, ISSN 0270-6474.

Yamaguchi, K. \& Watanabe, K. (2004). Pursuit of roles for metabotropic glutamate receptors in the anteroventral third ventricular region in regulating vasopressin secretion and 
cardiovascular function in conscious rats. Brain Res Bull, Vol.63, No.4, (May 2004), pp. 321-329, ISSN 0361-9230.

Ye, P.; Mariniello, B.; Mantero, F.; Shibata, H. \& Rainey, W.E. (2007). G-protein-coupled receptors in aldosterone-producing adenomas: a potential cause of hyperaldosteronism. J Endocrinol, Vol.195, No.1, (October 2007), pp. 39-48, ISSN 0022-0795.

Zerbib, F.; Keywood, C. \& Strabach, G. (2010). Efficacy, tolerability and pharmacokinetics of a modified release formulation of ADX10059, a negative allosteric modulator of metabotropic glutamate receptor 5: an esophageal $\mathrm{pH}$-impedance study in healthy subjects. Neurogastroenterol Motil, Vol.22, No.8, (August 2010), pp. 859-865, ISSN 1350-1925. 


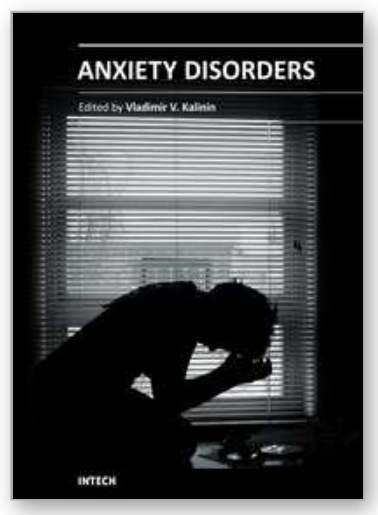

\author{
Anxiety Disorders \\ Edited by Prof. Vladimir Kalinin
}

ISBN 978-953-307-592-1

Hard cover, 324 pages

Publisher InTech

Published online 01, August, 2011

Published in print edition August, 2011

During the last 2-3 decades drastic research progress in anxiety issues has been achieved. It concerns mostly the study of different subtypes of anxiety and their treatment. Nevertheless, the data on anxiety pathogenesis is less elaborated, although here a multidimensional approach exists. It includes neurochemistry, pathophysiology, endocrinology and psychopharmacology. Again, we are able to recognize the multifarious sense of anxiety, and the present collective monograph composed of 16 separate chapters depicting the different aspects of anxiety. Moreover, a great part of book includes chapters on neurochemistry, physiology and pharmacology of anxiety. The novel data on psychopathology and clinical signs of anxiety and its relationship with other psychopathological phenomena is also presented. The current monograph may represent an interest and be of practical use not only for clinicians but for a broad range of specialists, including biochemists, physiologists, pharmacologists and specialists in veterinary.

\title{
How to reference
}

In order to correctly reference this scholarly work, feel free to copy and paste the following:

Daniela Durand, Lila Carniglia, Carla Caruso and Mercedes Lasaga (2011). Metabotropic Glutamate Receptors in Peripheral Tissues: Implications for Toxicology, Anxiety Disorders, Prof. Vladimir Kalinin (Ed.), ISBN: 978-953-307-592-1, InTech, Available from: http://www.intechopen.com/books/anxietydisorders/metabotropic-glutamate-receptors-in-peripheral-tissues-implications-for-toxicology 1

\section{INTECH}

open science | open minds

\section{InTech Europe}

University Campus STeP Ri

Slavka Krautzeka 83/A

51000 Rijeka, Croatia

Phone: +385 (51) 770447

Fax: $+385(51) 686166$

www.intechopen.com

\section{InTech China}

Unit 405, Office Block, Hotel Equatorial Shanghai

No.65, Yan An Road (West), Shanghai, 200040, China 中国上海市延安西路65号上海国际贵都大饭店办公楼 405 单元

Phone: +86-21-62489820

Fax: +86-21-62489821 
(C) 2011 The Author(s). Licensee IntechOpen. This chapter is distributed under the terms of the Creative Commons Attribution-NonCommercialShareAlike-3.0 License, which permits use, distribution and reproduction for non-commercial purposes, provided the original is properly cited and derivative works building on this content are distributed under the same license. 